УДК 347.73

DOI https://doi.org/10.32837/pyuv.v2i4(29).448

\author{
О.О. Мамалуй \\ orcid.org/0000-0003-0667-4746 \\ кандидат юридичних наук, суддя \\ Верховного Суду
}

\title{
ПІДСТАВИ ВИНИКНЕННЯ, ЗМІНИ ТА ПРИПИНЕННЯ ПОДАТКОВИХ ВІДНОСИН
}

Будь-які суспільні відносини мають унікальну, неповторну структуру, характер якої зумовлюється конкретними обставинами розвитку таких відносин. Регламентовані правом відносини мають своєрідний «життєвий цикл», який в умовній, ідеальній моделі можна позначити так:

а) виникнення відносин;

б) розвиток відносин;

в) зміна відносин;

г) припинення відносин.

Умовність такої моделі пов'язана з відносністю розвитку відносин, їнім неповторним характером. Якщо об’єктивно ми можемо говорити, що будь-які відносини виникають та припиняються, то не про всі відносини можна сказати як про такі, що зазнають трансформації (зміни). Зміна регламентованих правом відносин факультативна - усе залежить від фактичного складу відносин. Сам же розвиток відносин є досить абстрактним поняттям, адже в темпоральному відношенні такий розвиток може мати різний рівень тривалості в часі. Водночас потрібно зазначити, що виникнення, зміна та припинення суспільних відносин не відбуваються самі собою. У відповідному відношенні виникнення, зміна та припинення правових відносин зумовлюються настанням конкретних підстав - певного юридичного факту. Не є винятком і податкові відносини.

Перед тим, як перейти до аналізу підстав виникнення, зміни та припинення податкових відносин, вбачається за доцільне проаналізувати наріжне теоретичне поняття «юридичний факт». 0.0. Красавчиков визначав юридичні факти як обставини об'єктивної реальності, суспільні явища, які існують незалежно від свідомості конкретного індивіда. Водночас науковець зазначав, що саме 3 настанням конкретного юридичного факту право пов'язує виникнення, зміну або ж припинення суспільних відносин [1, с. 27]. Ми повинні чітко усвідомлювати, що юридичні факти можуть «породжуватися» саме активною та цілеспрямованою діяльністю конкретних індивідів. У зв’язку із цим твердження про те, що юридичні факти це завжди явища, які існують незалежно від свідомості суб’єктів права, не є цілком правильним. Позиція автора буде доречна тільки тоді, коли йдеться про такий різновид юридичних фактів, як події.

В.Б. Ісаков визначає юридичні факти як певні суспільні обставини, з якими нормативні припи- си пов'язують можливість виникнення, зміни та припинення правових відносин [2, с. 10]. Відповідне визначення юридичних фактів є лаконічним і таким, що визначає іманентні риси юридичних фактів. М.Г. Александров розглядає юридичні факти як різновид життєвих обставин (або ж комплекс обставин, які формують певний юридичний склад), з наявністю яких право пов'язує виникнення, зміну або ж припинення юридичних прав і обов'язків [4, с. 547]. Автор влучно підмітив, що в окремих випадках для виникнення, зміни або ж припинення правових відносин необхідне настання не просто одиничного юридичного факту, а цілої низки юридичних фактів, які формують специфічний юридичний склад. Тільки за умови наявності такого юридичного складу можна говорити про наявність підстав для виникнення, зміни або припинення правовідносин.

Р.О. Халфіна визначає юридичні факти як конкретний акт поведінки особи, який може мати вольовий характер або ж реалізовуватися поза волею особи, який, зрештою, запускає механізм нормативного регулювання [4, с. 286]. У такому разі важко погодитися із твердженням, що юридичний факт є актом поведінки особи. Крім того, спірним є твердження про те, що акт поведінки особи може не мати вольового характеру. Акт поведінки особи завжди має вольовий характер. B.B. Копейчиков визначає юридичний факт як реальні життєві обставини, з якими приписи права пов'язують виникнення, зміни чи припинення регламентованих правом суспільних відносин [5, с. 193]. 3 відповідного визначення вбачається, що автор пішов шляхом стислого та змістовно-сконцентрованого формулювання дефініції досліджуваного поняття.

В.В. Муругіна розглядала юридичний факт крізь призму його дихотомічного (подвійне) розуміння - ідеальна (нормативна конструкція-модель) та матеріальна (як явище об'єктивної дійсності) складові частини його розуміння [6]. П.М. Рабінович уважає, що під юридичним фактом потрібно розуміти визначену гіпотезою нормативного припису обставину, з наявністю якої право пов'язує виникнення, зміну або ж припинення правовідносин [7, с. 84]. Науковець звертає увагу на те, що юридичний факт - не просто обставина об'єктивної дійсності, але й така обставина, яка визначається нормою права. 
П.О. Якушев детермінує юридичний факт як суспільно зумовлені обставини реального життя, які $є$ інтегративним елементом правового регулювання, які прямо або опосередковано детермінуються нормативними приписами та з наявністю або ж відсутністю яких у праві передбачається настання конкретних наслідків, а саме:

а) виникнення правовідношення;

б) зміна правовідношення;

в) припинення правовідношення [8, с. 147].

Дане визначення розвинуло позицію попереднього дослідника шляхом акцентування уваги на тому, що вказівка на відповідні юридично значущі обставини може мати прямий або ж опосередкований характер. З.Д. Іванова визнала юридичні факти як об'єктивно необхідну передумову виникнення прав і обов'язків учасників суспільних відносин [9, с. 32]. Науковець вказує на те, що юридичні факти не просто є підставою для виникнення, зміни або ж припинення правових відносин - вони є передумовою виникнення прав і обов'язків учасників таких відносин. Розвиваючи дану позицію, буде доречним зазначити, що юридичні факти не тільки являють собою підставу для виникнення правових відносин, вони також можуть виступати підставою для зміни та припинення прав та / або обов'язків учасників суспільних відносин.

Проаналізувавши всі вищеозначені підходи до визначення поняття «юридичні факти», можемо запропонувати таку дефініцію відповідного терміна: юридичний факт - це визначена гіпотезою норми права обставина об'єктивної дійсності (одинична обставина) або ж комплекс обставин (юридичний склад), з наявністю яких у праві передбачаються виникнення, зміна або ж припинення правових відносин, у рамках яких відповідні суб'єкти права реалізують належні їм права й обов'язки.

Низка науковців визначали також систему ознак, які в загальнотеоретичному сенсі характеризують юридичні факти. Так, система ознак юридичних фактів була запропонована В.М. Протасовим. До ознак науковець відносить таке:

- соціальна природа юридичних фактів вказує на те, що вони являють собою обставини об'єктивної дійсності, які можуть викликати настання юридично значущих наслідків тільки за визначеності такої їхньої властивості в рамках правових норм;

- юридичні факти опосередковано визначають порядок руху правовідносин (виникнення, зміну та припинення відносин);

- юридичні факти здатні призвести до виникнення, зміни або ж припинення правових відносин тільки на основі нормативних приписів, тобто у взаємодії з ними;

- юридичні факти детермінуються в рамках правових положень (зокрема, у рамках норма- тивних приписів міститься вказівка на конкретні юридичні факти) [10].

Власна система ознак юридичних фактів була запропонована й таким науковцем, як Ю.М. Оборотов. Так, учений визначає такі ознаки юридичних фактів:

- обгрунтованість;

- законність;

- можливість породжувати юридично значущі наслідки;

- оформленість;

- інформативність;

- дієвість [11, с. 57].

М.В. Бородкін, досліджуючи юридичні факти у праві соціального забепечення, формулює власну систему їхніх ознак. Якщо проаналізувати їх крізь призму загальнотеоретичного підходу, то вони матимуть такий вигляд:

- конкретизований характер юридичних фактів, який полягає в тому, що виключно обставини об'єктивної дійсності можуть призводити до настання юридично значущих наслідків;

- наявність зовнішнього втілення юридичних фактів, адже для правозастосування мають значення виключно факти, які відображено в об'єктивній дійсності;

- інформативність, яка полягає в доведені до відома суб'єктів правозастосування інформації про поточний стан правовідносин;

- опосередковане нормативними приписами існування юридичних фактів - відсутність нормативного припису унеможливлює існування юридичних фактів, водночас без юридичного факту не можуть настати які-небудь юридично значущі наслідки;

- формальна визначеність, яка полягає в зафіксованості юридичних фактів у конкретній процедурній (процесуальній) формі;

- наявність причинно-наслідкових зв'язків юридичний факт передує настанню правових наслідків[12, с. 134].

3-поміж вищезазначених ознак юридичних фактів критично потрібно поставитися до таких ознак, як інформативність та формальна визначеність. Так, юридичні факти можуть мати місце і без їх усвідомлення з боку учасників суспільних відносин. Що ж стосується процедурної оформленості, то вона також не завжди необхідна, наприклад, коли йдеться про матеріальні за своїм характером відносини.

Потрібно також зазначити, що натепер склалися різні підходи до класифікації юридичних фактів. Найбільш поширений підхід, з яким юридичні факти підрозділяють за критеріями їх прояву. Так, В.С. Якушев підрозділяв юридичні факти на:

a) явища;

б) стани.

Останні, на думку науковця, характеризуються темпоральною продовжуваністю [13]. В.М. Горшиньов також класифікував юридичні факти на: 
а) факти-явища;

б) факти-стани.

Факти-стани науковець розглядав в їхній нерозривній єдності із процедурними (процесуальними) строками [14, с. 113-118]. На основі вищезазначеного критерію С.С. Алексєєв підрозділяв юридичні факти на:

а) факти однократної дії (факти-явища);

б) факти безперервної дії (факти-стани).

Факти обмеженої дії, на думку науковця, $€$ обставинами реального життя, з якими нормативні приписи пов'язують настання правових юридичних наслідків у конкретний момент часу. Що ж стосується фактів-станів, то під ними науковець пропонує розуміти обставини суспільної дійсності, які існують протягом тривалого часового відрізка та здатні перманентно або ж періодично породжувати правові наслідки [15, с. 177].

Варто зауважити, що у правовій доктрині $€$ і протилежний підхід - підхід, відповідно до якого юридичних фактів-станів не існує. Такої позиції дотримувалися Р.О. Халфіна та С.Ф. Кечек'ян. Так, Р.О. Халфіна зазначала, що «юридичний факт-стан» є радше триваючими правовідносинами, а не окремим різновидом юридичних фактів. У свою чергу, С.Ф. Кечек'ян, конкретизуючи відповідну позицію, зауважив, що продовжуваний стан не може детермінуватися як самостійний юридичний факт, адже правове значення має не сам стан (шлюб, трудові відносини) як правова категорія, а юридичні факти, які породжують такий стан [16, с. 173-174]. У даному разі варто зазначити, що такого роду позиція є цілком слушною. Такого роду підхід зумовлюється тим, що стан $€$ темпорально продовжуваним явищем, не має одномоментного прояву та призводить до настання конкретного юридичного наслідку (наслідків). Правовий стан радше є правовідношенням, що має відносно тривалий період існування, проте аж ніяк не підставою для виникнення, зміни та припинення правових відносин. Так, юридичні факти, породжують, змінюють або ж припиняють правовідношення (стан), яке може мати різний продовжуваний період існування.

Для класифікації юридичних фактів застосовуються також інші критерії, зокрема, вольовий критерій. Як зазначає В.Б. Ісакова, на основі даного критерію юридичні факти підрозділяються на дії та події [17]. Так, дії - це юридичні факти, які породжуються за посередництвом активної волі учасника суспільних відносин. Що ж стосується подій, то вони є явищем об'єктивної дійсності, що настає незалежно від волі та бажання особи.

Ще одним критерієм для класифікації юридичних фактів є форма прояву юридичних фактів. На основі даного критерію 0.О. Красавчиков поділяє юридичні факти на: а) позитивні;

б) негативні.

Під позитивними юридичними фактами науковець розумів факти, які визначають явища, які об'єктивно існували в певному проміжку часу. Коли ж ідеться про негативні юридичні факти, то під ними потрібно розуміти юридичні факти, які вказують на відсутність конкретних явищ і станів [18].

Загалом потрібно зазначити, що існують ще ціла низка критеріїв для підрозділення юридичних фактів як на загальнотеоретичному, так і на галузевому рівнях. Водночас убачається за доцільне більш предметно розглянути їх в аспекті дослідження підстав для виникнення, зміни та припинення податкових відносин.

Податкові відносини є специфічним різновидом суспільних відносин. Специфіка податкових відносин зумовлюється самим предметом правового регулювання - рухом публічних фінансів на стадії їх акумуляції у процесі виконання платниками податків свого обов' язку зі сплати загальнообов'язкових платежів податкового характеру та методом правового регулювання - імперативним методом (метод владних приписів). Підставою для виникнення, зміни або ж припинення податкових відносин є юридичні факти, вказівка на які набуває безпосередньої формалізації в рамках приписів податкового законодавства. До податкового законодавства належать:

а) Конституція України;

б) Податковий кодекс України;

в) Митний кодекс України й інші закони з питань митної справи в частині регулювання правовідносин, що виникають у зв'язку з оподаткуванням митом операцій із переміщення товарів через митний кордон України;

г) чинні міжнародні договори, згода на обов'язковість яких надана Верховною Радою України і якими регулюються питання оподаткування;

г) нормативно-правові акти, ухвалені на підставі та на виконання Податкового кодексу України та законів із питань митної справи;

д) рішення Верховної Ради Автономної Республіки Крим, органів місцевого самоврядування 3 питань місцевих податків та зборів [19].

У подальшому пропонується проаналізувати окремі критерії для класифікації юридичних фактів у податковому праві.

Вольовий критерій. На основі вольового критерію юридичні факти в податковому праві можуть бути підрозділені на:

а) юридичні факти-дії;

б) юридичні факти-події.

Так, юридичними фактами-діями у сфері оподаткування можуть виступати активні дії контролюючого органу або ж платника податків. Крім вищеозначених суб'єктів, суб'єктом реалізації 
таких дій можуть виступати й треті особи (органи місцевого самоврядування, інші органи державної влади тощо). Прикладом юридичного факту-дії може слугувати прийняття контролюючим органом податкового повідомлення-рішення, направлення платнику податків запиту про надання інформації, сплата правозобов'язаним учасником податкових відносин податків та зборів тощо. Що ж стосується юридичних фактів-подій, то вони є обставинами об’єктивної дійсності, які настають незалежно від волі учасників податкових відносин. Прикладом юридичних фактів-подій є момент спливу трирічного строку, який дає можливість контролюючому органу призначити проведення планової перевірки, досягнення певного рівня грошового обороту платником податків тощо.

Критерій прояву юридичних фактів. Залежно від специфіки прояву юридичних фактів у податковому праві вони можуть бути підрозділені на:

а) позитивні юридичні факти в податковому праві;

б) негативні юридичні факти в податковому праві.

Позитивними юридичними фактами у срері оподаткування є обставини, які набувають об’єктивації в суспільному житті. До таких юридичних фактів можна віднести реєстрацію платником податків, ухвалення місцевою радою рішення про встановлення місцевого податку або ж збору тощо. $\mathrm{y}$ свою чергу, негативними юридичними фактами є обставини, з відсутністю яких пов'язують наявність певного правового статусу у платника податків. Наприклад, відсутність певної суми грошового обороту та/або не перевищення гранично допустимої кількості працівників дозволяє платнику податків перебувати на спрощеній системі оподаткування. Як ми бачимо, відповідний різновид юридичних фактів має досить умовний характер, адже пов'язаний із констатацією відсутності певних обставин як об'єктивної умови існування конкретного правового статусу.

Критерій правореалізаційного або ж правозастосовного складу. Так, за вищезазначеним критерієм юридичні факти у сфері оподаткування можна класифікувати на:

а) прості юридичні факти;

б) складні юридичні факти.

Під простими юридичними фактами потрібно розуміти одиничну обставину, з якою в податковому праві пов'язуються виникнення, зміна або ж припинення податкових відносин. Наприклад, настання конкретної календарної дати зумовлює необхідність сплати податку, подання звітності тощо. Якщо ж ідеться про складні юридичні факти, то під ними потрібно розуміти юридичні склади (два або більше юридичні факти), з наявністю або ж відсутністю яких податкове право визначає настання юридично значущих наслідків. Як приклад можна навести процедуру допуску контролюючого органу до виїзної перевірки, за якої для можливості реалізації контрольних заходів повинні бути наявними такі умови:

а) наказ про призначення перевірки;

б) направлення на проведення перевірки;

в) службове посвідчення посадових осіб контролюючого органу.

Без наявності одного з вищезазначених елементів (юридичних фактів) платник податків має право не допустити посадових осіб контролюючого органу до проведення відповідних контрольних заходів.

Отже, юридичні факти, вказівка на які набуває фіксації у приписах податкового законодавства, являють собою підставу для виникнення, зміни або ж припинення податкових відносин. Варто зауважити, що 3 огляду на публічно-правовий характер податкового права, імперативність його приписів, на відміну від приватноправових галузей права, зазвичай не може встановлюватися на основі диспозитивної волі учасників податкових відносин (наприклад, у договорі) - юридичні факти у сфері оподаткування детермінуються приписами податкового законодавства.

\section{Jimepamypa}

1. Красавчиков О.А. Юридические факты в советском гражданском праве : монография. Москва : Госюриздат, 1958.184 с. С. 27.

2. Исаков В.Б. Юридические факты в советском праве : монография. Москва : Юрид. лит., 1984. 144 с. C. 10 .

3. Теория государства и права : учебник / Н.Г. Александров и др. ; под. ред. Н.Г. Александрова. Москва : Юрид. лит., 1968.640 с. С. 547.

4. Халфина Р.О. Общее учение о правоотношении : монография. Москва : Юрид. лит., 1974. 351 с. С. 286.

5. Загальна теорія держави і права / за ред. В.В. Копейчикова. Київ : Юрінком-Інтер, 1997. 320 с. С. 193.

6. Воротников А.А., Муругина В.В. Дефектность юридических фактов как негативная черта правовой системы. Саратов : Изд-во ФГБОУ ВПО «Сарат. гос. юр. акад.», 2011. 192 с.

7. Рабінович П.М. Основи загальної теорії права та держави : навчальний посібник. 5-те вид., зі змін. Київ :Атіка, 2001. 174 с. С. 84.

8. Якушев П.О. Правообразующие юридические акты и поступки в механизме правового регулирования : дис. ... канд. юрид. наук: 12.00.01. Москва, 2004. 165 c. C. 147.

9. Иванова З.Д. Юридические факты и возникновение субъективных прав граждан. Советское государство и право. 1980. № 2. С. 31-37. С. 32 .

10. Протасов В.Н. Теория права и государства. Проблемы теории права и государства : вопросы и ответы. Москва : Новый юрист, 1999. 240 с.

11. Оборотов Ю.Н. Теория государства и права : прагматический курс. Одесса : Юридическая литератуpa, 2004.184 c. С. 57.

12. Бородкін М.В. Ознаки юридичних фактів у праві соціального забезпечення. C. 134. URL: http://www. visnyk-juris.uzhnu.uz.ua/file/No.42/31.pdf. 
13. Якушев В.С. Юридическая личность государственного производственного предприятия. Свердловск : Средне-Уральское книжное изд-во, 1973. 240 с.

14. Горшенев В.М. Нетипичные нормативные предписания. Советское государство и право. 1978. № 3. C. $113-118$.

15. Алексеев С.С. Общая теория права : курс : в 2-х т. Москва : Юрид. лит., 1982. Т. 2. С. 177.

16. Качекьян С.Ф. Правоотношения в социалистическом обществе. Москва : АН СССР, 1958. С. 173-174.

17. Исаков В.Б. Юридические факты в советском праве. Москва : Юрид. лит., 1984. 144 с.

18. Красавчиков О.А. Юридические факты в советском гражданском праве. Москва : Госюриздат, 1958. $184 \mathrm{c}$.

19. Податковий кодекс України, у редакції від 11 грудня 2019 p. URL: https://zakon.rada.gov.ua/ laws/show/2755-17.

\section{Анотація}

Малалуй О. О. Підстави виникнення, зміни та припинення податкових правовідносин. - Стаття.

У науковій роботі проаналізовано підходи до визначення фундаментального теоретичного поняття «юридичний факт» 3 погляду різних авторів, а також визначено розбіжності в детермінації поняття «юридичний факт» у наукових дослідженнях. 3 огляду на наявність таких розбіжностей автором запропоновано власне визначення поняття юридичного факту як визначеної гіпотезою норми права обставини об'єктивної дійсності (одинична обставина) або ж комплексу обставин (юридичний склад), з наявністю яких у праві передбачаються виникнення, зміна або ж припинення правових відносин, у рамках яких відповідні суб'єкти права реалізують належні їм права й обов'язки. Здійснено порівняльний аналіз ознак, притаманних юридичним фактам, акцентовано увагу на необхідності вдосконалення переліку специфічних рис юридичних фактів. Автором розглянуто найбільш поширені підходи до диференціації юридичних фактів як на загальнотеоретичному, так і на галузевому рівнях, за критеріями їх прояву, вольовим і темпоральним критерієм, формою прояву юридичних фактів. Водночас класифікація юридичних фактів за критеріями їх прояву є складною, інтегративною, адже містить підкласифікації. Досліджено відмінності в підходах різних науковців до класифікації юридичних фактів на основі критерію ïx прояву. Критерії класифікації юридичних фактів предметно розглянуто в аспекті дослідження підстав для виникнення, зміни та припинення податкових відносин. Підставою для виникнення, зміни або ж припинення податкових відносин є юридичні факти, вказівка на які набуває безпосередньої формалізації в рамках приписів податкового законодавства. Для класифікації податкових відносин автором виділено критерій правореалізаційного або ж правозастосовного складу, критерій прояву юридичних фактів і вольовий критерій. Наголошено на неможливості встановлення i фіксації юридичних фактів на основі диспозитивної волі учасників податкових відносин, адже юридичні факти у сфері оподаткування детермінуються приписами податкового законодавства через публічно-правовий характер податкового права, імперативність його приписів.

Ключові слова: юридичний факт, класифікація, податкові відносини, підстави виникнення, зміни та припинення податкових відносин.

\section{Summary}

Mamalui 0 . 0 . The grounds for occurrence, change and termination of tax relations. - Article.

Approaches to defining the fundamental theoretical concept of "legal fact" from the point of view of different authors have been analyzed in the scientific work, as well as the differences in the determination of the concept of "legal fact" in scientific researches. Considering the existence of such differences, the author proposes his own definition of the concept of legal fact as a hypothesized norm of the law of objective reality (single circumstance) or a set of circumstances (legal composition), with the presence of which the law presupposes the occurrence, change or termination of legal relations, within which the relevant entities exercise their rights and obligations. The comparative analysis of the features inherent in legal facts has been carried out, the attention is focused on the need to improve the list of specific features of legal facts. The author considers the most widespread approaches to differentiation of legal facts, both at the theoretical and sectoral level, by the criteria of their manifestation, volitional and temporal criteria, the form of manifestation of legal facts. In this case, the classification of legal facts by the criteria of their manifestation is complex, integrative, because it contains subclassifications. The differences in the approaches of different scholars to the classification of legal facts based on the criterion of their manifestation are investigated. The criteria for the classification of legal facts have been examined in detail in the aspect of the study of the grounds for the occurrence, change and termination of tax relations. The basis for the occurrence, change or termination of tax relations are legal facts, the indication of which receives its direct formalization in the framework of tax legislation. For the classification of tax relations the author distinguishes the criterion of the right-to-implement or enforceable composition, the criterion of manifestation of legal facts and the volitional criterion. It is emphasized that impossibility of establishing and fixing legal facts on the basis of the dispositive will of the participants in tax relations, because legal facts in the field of taxation are determined by the provisions of tax legislation due to the public law nature of tax law, its imperativeness.

Key words: legal fact, classification, tax relations, grounds for occurance, change and termination of tax relations. 